\title{
A rapid, simple assay for digoxin
}

\author{
HELENA GREENWOOD, M. HOWARD, AND J. LANDON
}

From the Department of Chemical Pathology, St Bartholomew's Hospital, London

SYNOPSIS An extremely rapid radioimmunoassay for digoxin is described which is precise over the range of concentrations required to determine whether, or not, a patient has digoxin toxicity. The assay is based on the use of ${ }^{125}$-iodine-labelled digoxin and of a gel equilibration technique for the separation of antibody-bound and free digoxin. The results obtained compare closely with those by a conventional radioimmunoassay and the technique is sufficiently simple to enable its performance by relatively inexperienced laboratory staff.

Since Butler and Chen (1967) described a method for producing antibodies to the cardiac glycosides, many radioimmunoassays for digoxin have been developed. It is now becoming apparent that a variety of such assays are needed according to the nature and urgency of a request.

1 A rapid but relatively insensitive assay is required for urgent samples from patients with suspected digoxin toxicity. Such requests are relatively infrequent; however, results are required with a minimum of delay and the assay should cover the clinically important range of concentrations ( 1 to $4 \mathrm{ng} / \mathrm{ml}$ ). Furthermore, the assay should, ideally, be so simple technically that it can be performed by laboratory personnel who are inexperienced in radioimmunoassay, since it is unlikely that experienced radioimmunoassayists will always be available.

2 A routine assay is required suitable for large numbers of samples from patients maintained on digoxin to ensure adequate control of their therapy. In this situation a rapid result is unnecessary but attention should be given to precision and cost.

3 A highly sensitive assay is required suitable for research samples and for the very small blood samples obtained by heelprick in neonatal practice.

This paper describes an assay developed to fulfil the requirements of the first type. It is based on the use of 125I-digoxin as tracer and of a gel equilibration technique for the separation of antibodybound and free digoxin.

\section{Materials and Methods}

Dixogin standards, ranging from 0.5 to $8.0 \mathrm{ng} / \mathrm{ml}$, were made up in digoxin-free plasma from stock Received for publication 8 March 1974. standards, prepared by dissolving crystalline digoxin (British Pharmacopia) in a minimum quantity of ethanol and diluting this appropriately with barbitone buffer ( $\mathrm{pH} \mathrm{7.4,0.035} \mathrm{M).}$

Digoxin antibodies were raised in rabbits by repeated subcutaneous injections of a digoxin-bovine serum albumin conjugate with Freund's adjuvant, as described by Smith, Butler, and Haber (1970). The antiserum employed was stored at $-20^{\circ}$ in small aliquots, one of which was thawed and diluted appropriately in barbitone buffer as required.

CONVENTIONAL ASSAY

This has been described previously (Chamberlain, White, Howard, and Smith, 1970) and employs ${ }^{3} \mathrm{H}$-labelled digoxin as tracer, a coated charcoal technique to adsorb free digoxin, and the counting of the bound fraction in liquid scintillant.

\section{RAPID ASSAY}

${ }^{125}$ I-digoxin, with a specific activity of approximately $500 \mathrm{Ci} / \mathrm{mMol}$, was supplied by Wellcome Reagents Ltd (Beckenham, Kent) and diluted to the concentration required with barbitone buffer. Samples were assayed in duplicate in glass vials containing $1 \mathrm{~g}$ $( \pm 1 \%$ ) of a molecular sieve and $5 \mathrm{ml}$ of phosphate buffer (pH 7.4, 0.05M), supplied by the Radiochemical Centre (Amersham, Bucks), and used by them as the basis of their Thyopac four test kit for thyroxine. To each vial was added $100 \mu l(500 \mathrm{pg})$ ${ }^{125}$ I-digoxin followed by $200 \mu \mathrm{l}$ of the sample (or standard) and the contents were then mixed thoroughly. Finally, $100 \mu \mathrm{l}$ of antiserum was added to each vial, at an initial dilution of 1:250 (this dilution of antiserum was chosen, since it bound approximately $60 \%$ of the labelled digoxin in the absence of unlabelled digoxin). All additions were 
made using a Finnpipette (Jencons Ltd, Hemel Hempstead, Herts) with a precision of $\pm 1 \%$.

The vials were equilibrated on a slowly rotating mixer at room temperature for 15 minutes and then left to stand. The gel settled quickly and $1 \mathrm{ml}$ of the supernatant, containing antibody-bound digoxin, was transferred to a plastic tube and counted for 10 seconds, using a manual gamma counter (Wilj Electronics Limited, Ashford, Kent). A standard curve was obtained by plotting counts on the ordinate against the digoxin concentrations of the digoxin concentrations of the standards expressed logarithmically on the abscissa. The digoxin concentration in the samples was then read from the standard curve.

\section{SAMPLES}

A total of 100 samples from patients receiving digoxin and 20 samples from subjects who had never received the drug were assayed by both methods. A plasma pool with a digoxin concentration within the clinically important range was assayed in duplicate 11 times by each method and repeated for six assays to determine 'within' and 'between' batch precision.

\section{Results}

\section{ASSESSMENT OF THE SUITABILITY OF GEL} EQUILIBRATION FOR THE ASSAY OF DIGOXIN Preliminary studies were performed to assess the suitability of the gel equilibration technique for the assay and the nature of the separation of the antibody-bound and free fractions. The partition of 125I-digoxin between the supernatant and gel in the reaction vial was studied with and without the addition of antiserum and of an excess of unlabelled digoxin (table I).

When $500 \mathrm{pg}$ of ${ }^{125}$ I-digoxin was added to $5 \mathrm{ml}$ of buffer alone, $1 \mathrm{ml}$ of the solution generated 447 cps, and the counts obtained were unaffected by the

\begin{tabular}{ll}
\hline Contents of Vial & $\begin{array}{l}\text { Counts per Second in } \\
1 \mathrm{ml} \text { of Supernatant }\end{array}$ \\
\hline $\begin{array}{l}\text { 125 I-digoxin }(500 \mathrm{pg}) \text { added to } 5 \mathrm{ml} \\
\text { buffer alone }\end{array}$ & 447 \\
$\begin{array}{l}225 \mathrm{I}-\text { digoxin }(500 \mathrm{pg}) \text { added to } 5 \mathrm{ml} \\
\text { buffer containing } 1 \mathrm{~g} \mathrm{gel}\end{array}$ & 406 \\
$\begin{array}{l}125 \mathrm{I}-\text { digoxin }(500 \mathrm{pg}) \text { added to } 5 \mathrm{ml} \\
\text { buffer containing } 1 \mathrm{~g} \text { gel and antiserum } \\
\text { 125I-digoxin }(500 \mathrm{pg}) \text { added to } 5 \mathrm{ml} \text { buffer } \\
\text { containing } 1 \mathrm{~g} \mathrm{gel,} \mathrm{antiserum} \mathrm{and} \mathrm{excess} \\
\text { unlabelled digoxin }\end{array}$ & 680 \\
\hline
\end{tabular}

Table I Effect of adding gel, antiserum, and unlabelled digoxin to ${ }^{125} \mathrm{I}$-digoxin in $5 \mathrm{ml}$ of buffer on counts generated by $1 \mathrm{ml}$ of supernatant presence of an excess of antibody and/or of unla.belled digoxin.

When the same amount of digoxin was added to $5 \mathrm{ml}$ of buffer containing $1 \mathrm{~g}$ of gel, such that most of the buffer was within the matrices of the gel, $1 \mathrm{ml}$ of the supernatant generated $406 \mathrm{cps}$. This indicates that the ${ }^{125} \mathrm{I}$-digoxin also freely permeated the gel and that, since only $90 \%$ of the expected counts were obtained in the supernatant, the gel must be acting as an adsorbent as well as a 'molecular sieve'. Addition of antibody (which is excluded by the gel) results in the binding of some labelled digoxin and, therefore, an increase in the counts obtained with $1 \mathrm{ml}$ of the supernatant to $680 \mathrm{cps}$. Addition of a large excess of unlabelled digoxin, which competes with the ${ }^{125}$ I-digoxin so that less is bound, results in most of the radioactivity being in the free fraction, so that it can again permeate into the matrices of the gel-as evidenced by a decrease of counts in $1 \mathrm{ml}$ of the supernatant to $422 \mathrm{cps}$. As would be expected, an inverse relationship was found between the amount of unlabelled digoxin added and the radioactivity present in $1 \mathrm{ml}$ of supernatant, over the range 422 to $680 \mathrm{cps}$.

DEVELOPMENT OF NEW ASSAY METHOD

Conditions were selected to improve the rapidity of the assay while maintaining precision over the most relevant clinical range to determine digoxin toxicity ( 1 to $4 \mathrm{ng} / \mathrm{ml}$ ). It was essential to use a large amount of labelled digoxin in each vial to ensure that sufficient counts were obtained in 10 seconds to reduce counting error to less than $2 \%$. Standard curves were compared using $250 \mathrm{pg}$ and $500 \mathrm{pg}$ of ${ }^{125} \mathrm{I}$-digoxin and the latter was chosen as the optimum concentration since it gave sufficient counts while maintaining the required sensitivity.

Optimim precision over the range 1 to $4 \mathrm{ng} / \mathrm{ml}$ was obtained by the addition of $200 \mu \mathrm{l}$ of plasma sample (or standard) together with $100 \mu \mathrm{l}$ of $1: 250$ dilution of antiserum. At these high concentrations of reactants the time taken to reach equilibrium was reduced to less than one hour and, for emergency purposes, an incubation period of 15 minutes was adequate (fig 1).

Prior addition of labelled digoxin to the vials did not significantly affect the results; however, it was not possible to add both ${ }^{125}$ I-digoxin and antiserum before addition to the sample since, under these circumstances, the unlabelled digoxin was unable to compete for antibody-binding sites and there was no significant change in the number of counts present in $1 \mathrm{ml}$ of supernatant.

Standard curves were compared using $5 \mathrm{ml}$ and $6 \mathrm{ml}$ of buffer in the vials. The former was chosen 


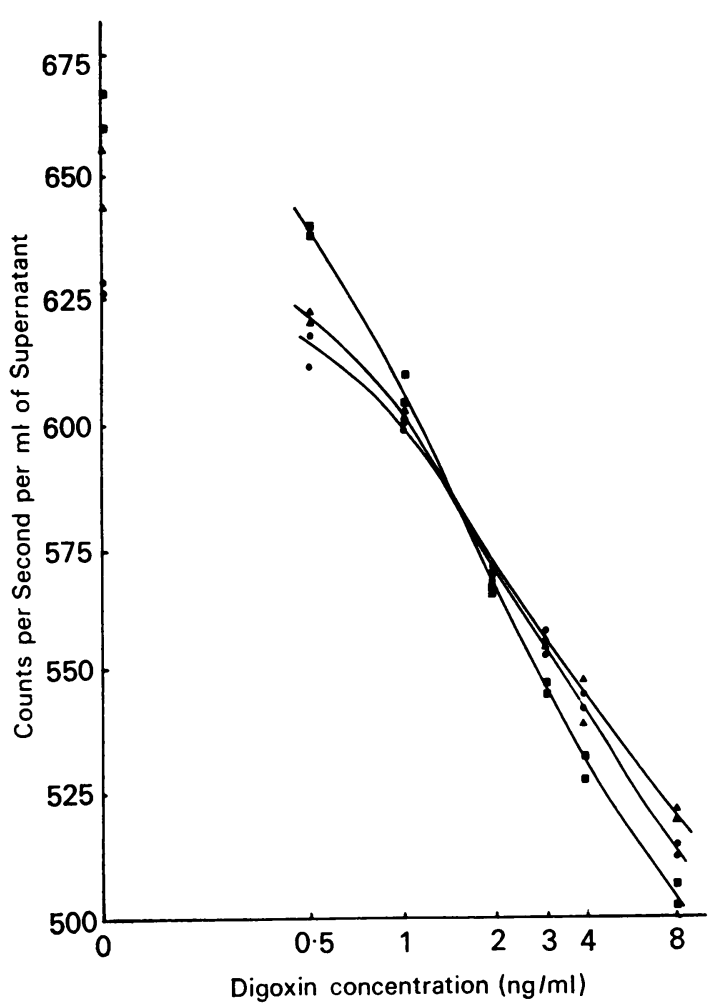

Fig 1 The effect on the standard curve of varying the time of incubation for $15(\mathbf{O}), 30(\mathbf{\Delta})$, or 60 minutes (ם).

as a compromise between a large volume, which enabled the easy removal of $1 \mathrm{ml}$ of supernatant, and a small volume when a high concentration of antibody-bound ${ }^{125} \mathrm{I}$-digoxin is obtained in the supernatant.

Once equilibrium had been reached the incubation mixture could be left for at least four hours before removal of the supernatant for counting, without affecting the result.

VALIDATION OF THE NEW ASSAY

The range of the assay was from 0.5 to $8.0 \mathrm{ng} / \mathrm{ml}$. Its specificity was tested by assaying plasma samples from 20 patients who were not receiving digoxin and none was detected.

When a single sample of digoxin-free plasma, to which a known amount of digoxin had been added, was assayed 10 times in duplicate, the mean value obtained was $2.5 \pm 0.2 \mathrm{ng} / \mathrm{ml}$ with a 'within-assay' coefficient of variation of $9.3 \%$ and an accuracy of $93 \pm 3 \%$. This study was repeated on six different days when the mean of all the assays was $2 \cdot 7 \pm 0.18$

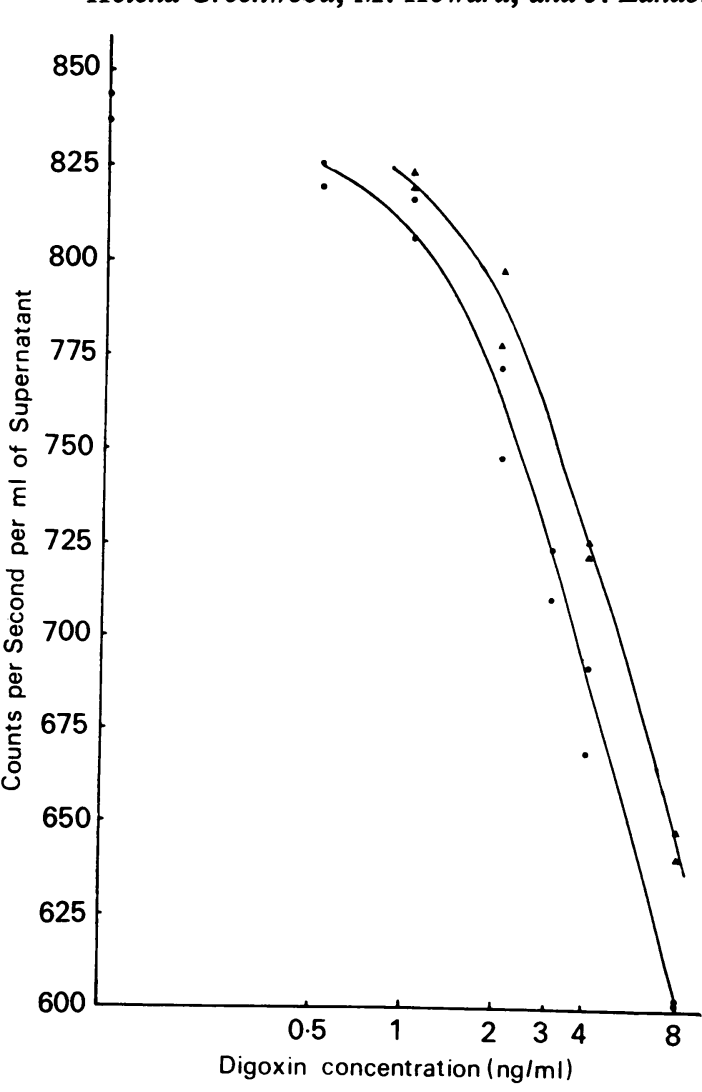

Fig 2 A typical standard curve $(\bullet)$ and dilutions of $a$ 'high' patient plasma $(\mathbf{\Delta})$ shown to be parallel.

$\mathrm{ng} / \mathrm{ml}$ and the 'between-assay' coefficient of variation was $6.9 \%$.

The results obtained with serial dilutions of $a$. patient's plasma, containing a high concentration 0 of digoxin, when plotted semilogarithmically gave a curve parallel to the standard curve (fig 2 ).

Correlation of the results obtained on 100 samples? assayed by this method and by the conventional assay, using ${ }^{3} \mathrm{H}$ digoxin, was linear (fig 3) with $N$ an $r$ value of 0.87 . The samples with a digoxin concentration greater than $2.5 \mathrm{ng} / \mathrm{ml}$ using the ${ }^{125}$ I-digoxin assay had a mean value $(3.6 \mathrm{ng} / \mathrm{ml}) \stackrel{\omega}{\sigma}$ significantly higher $(\mathbf{P}<0.001)$ than that obtained with the conventional assay $(2.7 \mathrm{ng} / \mathrm{ml})$. Values ${ }^{\circ}$ below $2.5 \mathrm{ng} / \mathrm{ml}$, however, did not show this differ- $\mathbb{D}$ ence (125I-digoxin assay, mean $1.19 \mathrm{ng} / \mathrm{ml} ;{ }^{3} \mathrm{H}^{\text {? }}$ digoxin assay, mean $1 \cdot 12 \mathrm{ng} / \mathrm{ml}$ ).

\section{Discussion}

Several radioimmunoassay methods for digoxin $\bar{C}$ have been described, some of which are summarized 


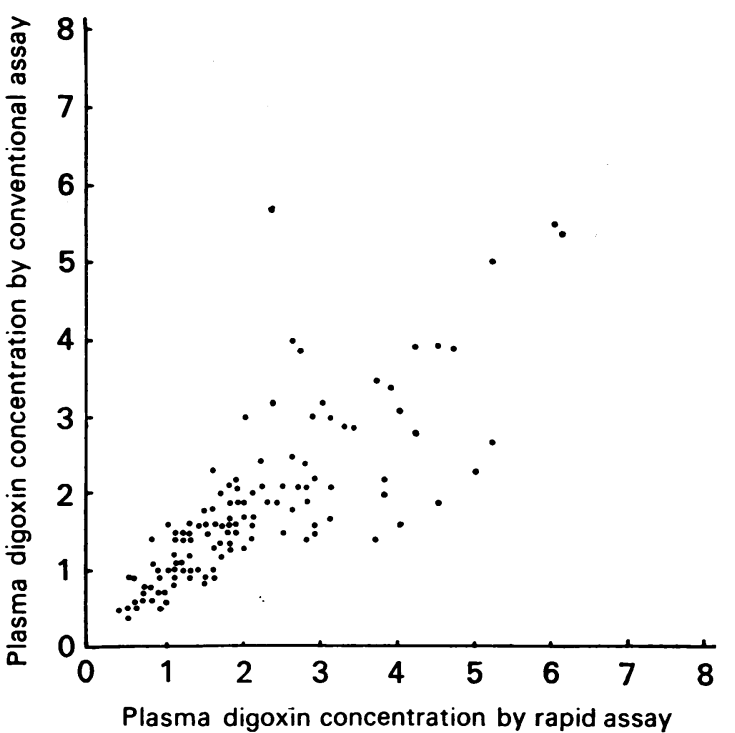

Fig 3 Correlation of plasma digoxin estimations by this assay, using ${ }^{125}$ I-labelled digoxin, and the conventional assay, using ${ }^{3} \mathrm{H}$ digoxin.

in table II. The advantages of the digoxin assay method discussed in this paper, which make it suitable for emergency purposes, are its speed, due to the high concentrations of reactants used and the high counts obtained with a gamma emitting isotope, and its simplicity, due to the use of a gel equilibration technique for separating bound and free digoxin.

The use of gamma-emitting isotopes in radioimmunoassay has several advantages over beta- emitting isotopes, such as ${ }^{3} \mathrm{H}$ and ${ }^{14} \mathrm{C}$. The assay is simplified and is less expensive because the antibodybound ${ }^{125}$ I-digoxin in the supernatant can be counted directly without the addition of scintillant and it is unnecessary to heat the supernatant to denature protein and, thereby, disrupt the antibody-digoxin complex. Counting is not affected by quenching as when beta-emitting isotopes are used, when improper correction for chemiluminescence or for chemical or colour quenching in haemolysed or jaundiced specimens may cause considerable inaccuracies. Furthermore, counting time is very much reduced using ${ }^{125}$ I-digoxin due to its high specific activity. Thus, in this assay, 1000 counts per second were obtained for the zero standard and counting times could be standardized at 10 seconds, whereas, using ${ }^{3} \mathrm{H}$-digoxin, the counting time must be prolonged in order to obtain sufficient counts to keep the counting error below $2 \%$. It must be noted, however, that plasma digoxin results using the rapid assay, with ${ }^{125} \mathrm{I}$-digoxin, are higher at concentrations greater than $2.5 \mathrm{ng} / \mathrm{ml}$ than those using the conventional assay with ${ }^{3} \mathrm{H}$-digoxin. This has also been noticed by us with our ${ }^{125}$ I-digoxin assay using charcoal to separate antibody-bound and free digoxin, and by Hansell, Hanser, and Herrera (1973). But Burnett, Conklin, Wasson, and MacKinney (1973) found the reverse. We are not able to explain this, but clinically, results greater than $2 \mathrm{ng} / \mathrm{ml}$ may be associated with toxicity and results less than $2 \mathrm{ng} / \mathrm{ml}$ exclude this.

Most radioimmunoassays for digoxin developed to date, whether using ${ }^{3} \mathrm{H}$-digoxin (Smith, Butler, and Haber, 1969; Chamberlain et al, 1970) or 125I-digoxin (Horgan and Riley, 1973), employ adsorption of the free fraction onto dextran-coated

\begin{tabular}{|c|c|c|c|c|}
\hline Reference & Label & Separation Technique & $\begin{array}{l}\text { Estimated Time of } \\
\text { Assay }\end{array}$ & $\begin{array}{l}\text { Range of Assay } \\
(\mathrm{ng} / \mathrm{ml})\end{array}$ \\
\hline Smith et al (1969) & ${ }^{3} \mathbf{H}$ & $\begin{array}{l}\text { Adsorption of free label onto } \\
\text { dextran-coated charcoal } \\
\text { (Herbert, 1965) }\end{array}$ & More than 1 hour & $0 \cdot 2-10 \cdot 0$ \\
\hline $\begin{array}{l}\text { Chamberlain et al (1970) } \\
\text { Evered et al (1970) } \\
\text { Oliver et al (1971) } \\
\text { Hoeschen and Proveda (1971) } \\
\text { Meade and Kleist (1972) }\end{array}$ & $\begin{array}{l}{ }^{2} \mathbf{H} \\
{ }^{2} \mathbf{H} \\
{ }^{2} \mathbf{H} \\
{ }^{2} \mathbf{H} \\
{ }^{2} \mathbf{H}\end{array}$ & $\begin{array}{l}\text { Dextran-coated charcoal } \\
\text { Dextran-coated charcoal } \\
\text { Dextran-coated charcoal } \\
\text { Dextran-coated charcoal } \\
\text { Somogyi precipitation } \\
\left(\mathrm{ZnSO}_{4}+\mathrm{NaOH}\right)\end{array}$ & $\begin{array}{l}\text { More than } 1 \text { hour } \\
\text { More than } 1 \text { hour } \\
21-3 \text { hours } \\
\text { More than } 1 \text { hour } \\
1 \text { hours }\end{array}$ & $\begin{array}{l}0 \cdot 5-8 \cdot 0 \\
0 \cdot 2-8 \cdot 0 \\
0 \cdot 25-5 \cdot 0 \\
0 \cdot 2-10 \cdot 0 \\
0 \cdot 4-10 \cdot 0\end{array}$ \\
\hline $\begin{array}{l}\text { Lader et al (1972) } \\
\text { Barrett and Cohen (1972) }\end{array}$ & ${ }^{2} \mathbf{H}$ & $\begin{array}{l}\text { Albumin-coated charcoal } \\
\text { Polyethylene glycol } \\
\text { precipitation }\end{array}$ & $\begin{array}{l}\text { More than } 1 \text { hour } \\
\text { More than } 1 \text { hour }\end{array}$ & $\begin{array}{l}0 \cdot 5-4 \cdot 0 \\
1 \cdot 0-5 \cdot 0\end{array}$ \\
\hline Lanoxitest (Wellcome Reagents Itd) & $\begin{array}{l}\text { 126I-labelled digoxin- } \\
\text { tyrosine conjugate }\end{array}$ & $\begin{array}{l}\text { Double antibody (Hales and } \\
\text { Randle, 1963) }\end{array}$ & More than 2 hours & $0 \cdot 5-6 \cdot 0$ \\
\hline Horgan and Riley (1973) & $\begin{array}{l}\text { 125I-labelled 3-0- } \\
\text { succinyl-digoxigenin } \\
\text { tyrosine derivative }\end{array}$ & Dextran-coated charcoal & More than 1 hour & $0 \cdot 2-8 \cdot 0$ \\
\hline This assay & $\begin{array}{l}\text { 126I-labelled digoxin- } \\
\text { tyrosine conjugate }\end{array}$ & Gel equilibration & 30 minutes & $0.5-8.0$ \\
\hline
\end{tabular}

Table II Available radioimmunoassays for digoxin 
charcoal for separating the bound and free digoxin. Other separation techniques have also been used in which the antibody-bound digoxin is precipitated by zinc sulphate (Meade and Kleist, 1972), by polyethylene glycol (Barrett and Cohen, 1972), or by a second antibody (Wellcome Lanoxitest $\gamma$ ). Such methods overcome the problem of time-dependence in the separation step which has been reported with charcoal; however, they increase the complexity and the time of assay thereby limiting its clinical application.

The gel equilibration technique is generally applicable to assays of the competitive proteinbinding type and has several advantages over other physico-chemical or immunological methods. The whole reaction takes place in the presence of the gel and, after standing for one minute, an aliquot of supernatant can be removed and counted without centrifugation. The dynamic equilibrium between antibody and antigen is unaffected by the removal of $1 \mathrm{ml}$ of supernatant for counting and, therefore, the separation is not time dependent. The action of the gel with digoxin is not merely as a 'molecular sieve' since some adsorption occurs, as evidenced by studies on the partition of digoxin between buffer and gel. This slight adsorption effect, also noted by others for steroid (Pearlman and Crepy, 1967) and non-steroid molecules (Gélotte, 1960), is constant over a wide range of digoxin concentrations and does not appear to affect the assay.

Satisfactory precision and accurancy were obtained and the sensitivity of the assay is sufficient for the purpose for which it is designed.

Developed in kit form, with ${ }^{125}$ I-digoxin dispensed in the vials together with the gel and buffer, the assay would be simpler, quicker and more precise. Operator error would be reduced to a minimum since only the addition of the plasma sample (or standard) and the antiserum would be required, and precision could be further improved by using a highly precise pipette. The assay, in this form, used in conjunction with the small inexpensive, manual Wilj gamma counter (which we found both accurate and convenient) would enable a plasma digoxin concentration to be determined rapidly by staff inexperienced in radioimmunoassay and would avoid the need for expensive equipment.

We wish to thank the Radiochemical Centre (Amersham) for supplying the assay vials and Wellcome Reagents Ltd for the supply of the 125I-digoxin.

HG and MH were supported in this work by a grant के from the British Heart Foundation.

\section{References}

Barrett, M. J., and Cohen, P. S. (1972). Radioimmunoassay of serum renin activity and digoxin concentrations, with the use of polyethylene glycol to separate free and antibody-bound ligand. Clin. Chem., 18, 1339-1342.

Burnett, G. H., Conklin, R. L., Wasson, G. W., and MacKinney, A. A. (1973). Variability of standard curves in radioimmunoassay of plasma digoxin. Clin. Chem., 19, 725-726.

Butler, V. P., Jr., and Chen, J. P. (1967). Digoxin-specific antibodies. Proc. nat. Acad. Sci. (Wash.), 57, 71-78.

Chamberlain, D. A., White, R. J., Howard, M. R., and Smith, T. W. (1970). Plasma digoxin concentrations in patients with atrial fibrillation. Brit. med. J., 3, 429-432.

Evered, D. C., Chapman, C., and Hayter, C. J. (1970). Measurement of plasma digoxin concentration by radioimmunoassay. Brit. med. J., 3, 427-428.

Gelotte, B. (1960). Studies on gel filtration: sorption properties of the bed material Sephadex. J. Chromatogr., 3, 330-342.

Hales, C. N., and Randle, P. J. (1963). Immunoassay of insulin with insulin-antibody precipitate. Biochem. J., 88, 137-146.

Hansell, J. R., Hanser, W., and Herrera, N. E. (1973). Analysis of the data from a quality evaluation program for nuclear medicine. J. nucl. Med., 14, 404.

Herbert, V., Lau, K., Gottlieb, C. W., and Bleicher, S. J. (1965). Coated charcoal immunoassay of insulin. J. clin. Endocr., 25, 1375-1384.

Hoeschen, R. J., and Proveda, V. (1971). Serum digoxin by radioimmunoassay. Canad. med. Ass. J., 105, 170-173.

Horgan, E. D., and Riley, W. J. (1973). Radioimmunoassay of plasma digoxin, with use of iodinated tracer. Clin. Chem., 19, 187-190.

Lader, S., Bye, A and Marsden, P. (1972). The measurement of plasma digoxin concentration: a comparison of two methods. Europ. J. clin. Pharmacol., 5, 22-27.

Meade, R. C., and Kleist, T. J. (1972). Improved radioimmunoassay of digoxin and other sterol-like compounds using Somogy precipitation. J. Lab. clin. Med., 80, 748-754.

Oliver, G. C., Parker, B. M. and Parker, C. W. (1971). Radioimmunoassay for digoxin. Amer. J. Med., 51, 186-192.

Pearlman, W. H., and Crépy, O. (1967). Steroid-protein interaction with particular reference to testosterone binding by human serum. J. biol. Chem., 242, 182-189.

Smith, T. W., Butler, V. P., Jr., and Haber, E. (1969). Determination of therapeutic and toxic serum digoxin concentrations by radioimmunoassay. New Engl. J. Med., 281, 1212-1216.

Smith, T. W., Butler, V. P., and Haber, E. (1970). Characterization of antibodies of high affinity and specificity for the digitalis glycoside digoxin. Biochemistry, 9, 331-337. 